\title{
TYÖELÄMÄN ULKOPUOLELLA OLEVAT JA ASUINALUEEN HYVÄ ARKI
}

\section{Siltaamalla vahvempia työelämävalmiuksia}

\section{Johdanto}

Työelämän ulkopuolella oleminen ja riski syrjäytyä kytkeytyvät toisiinsa (OECD 2010). Lukuisat tutkimukset osoittavat, että työttömyys ja sen pitkittyminen ovat yhteydessä alentuneeseen toimintakykyyn ja hyvinvointiin (vrt. Vuorento \& Terävä 2014). Syrjäytyminen on prosessi, jossa yksilöä yhteiskuntaan liittävät sidokset löystyvät (vrt. Heikkilä 2000). Yhteiskunta ja työelämä toimivat yhä verkostomaisemmin. Työelämävalmiuksien vahvistamisen näkökulmasta keskeinen kysymys on, miten työelämän ulkopuolella olevien yhteiskuntaan liittäviä sidoksia voitaisiin vahvistaa, jotta heidän syrjäytymisriskinsä pienenisi ja heidän työllistymisedellytyksensä paranisivat.

Työelämän ulkopuolella olevien työelämävalmiuksia ja työllistymisedellytyksiä tuetaan monin tavoin eri yhteyksissä. Tyypillisiä konteksteja ovat esimerkiksi työvoimapalvelujen, sosiaaliturvan, koulutuksen, kuntoutuksen, terveydenhuolto- ja sosiaalipalvelujen sekä työpaikkojen tuottamat keinovalikoimat (vrt. Vuorento \&t Terävä 2014). Tyypillisesti työelämän ulkopuolella olevat nähdään tukitoimien kohteina, ja heidät kutsutaan mukaan valmiiksi suunniteltuun toimintaan.

Tavallisten työmarkkinoiden rinnalle voidaan hahmottaa niin sanotut välityömarkkinat. Työ- ja elinkeinoministeriö määrittelee välityömarkkinoiden tarkoittavan työskente- lymahdollisuuksia sekä työllistymistä edistäviä ja työssä selviytymistä tukevia palveluja, joita tarjotaan avoimille työmarkkinoille sijoittumisessa eri syistä vaikeuksia kohdanneille työnhakijoille (von Hertzen-Oosi ym. 2010). Voidaan kysyä, vastaavatko kahdenlaisten työmarkkinamaailmojen ratkaisut yhteiskunnalliseen työllistymisen tukemisen haasteeseen. Millaisia uudenlaisia ratkaisuja tarvittaisiin välityömarkkinoiden rinnalle, työelämän ulkopuolella olevien henkilöiden työelämävalmiuksien vahvistamiseksi?

Tässä kirjoituksessa mielenkiinnon kohteena ovat käytännön ratkaisut, joilla tuetaan heikossa työmarkkina-asemassa olevia ja joilla voisi vastata työelämässä pärjäämisen vaatimuksiin. Miten käytännössä toimitaan, kun lähtökohtana ei ole yksilön työelämän ulkopuolisuuden aste tai diagnoosi? Tai mikä toimintatapa auttaisi työelämän ulkopuolella olevaa kehittämään työelämässä vaadittavia työelämävalmiuksiaan ja suuntaamaan omaa ajatteluaan kohti työelämää ja työllistymistä?

Työelämän ulkopuolella olevien henkilöiden työelämävalmiuksien ja työllistymisedellytysten vahvistamista tarkastellaan tässä asiakasymmärryksen, verkostotoiminnan ja yhteiskehittämisen näkökulmista. Kirjoitus liittyy juuri käynnistyneeseen Työste-hankkeseen (Työelämän ulkopuolella olevien työelämävalmiuksien ja työllistymisedellytysten 
vahvistaminen siltaustoiminnan avulla, ESR 2015-2017). Hankkeen päätavoitteena on vahvistaa työelämän ulkopuolella olevien henkilöiden työelämävalmiuksia ja työllistymisedellytyksiä kehittämällä paikallista siltaustoimintaa työ- ja toimintakyvyn tukemiseksi.

\section{Työste-hanke kokeiluympäristönä}

Pilottiympäristönä Työste-hankkeessa on itähelsinkiläinen Myllypuron alue. Myllypuro on lähiö, jonka rakentaminen alkoi 1960-luvulla. Alueella asuu monia erilaisia väestöryhmiä. Myllypuro on dynaaminen alue, jolla on vahva, oma alueellinen identiteettinsä. Metroasema ja ostoskeskuksen ympäristö kokevat juuri täydellistä muodonmuutosta, ja ostoskeskus uudistuu moderniksi ja monipuoliseksi palvelukeskittymäksi. Myllypuron alueella on runsaasti työttömyyttä, ja muualta muuttaneita on paljon. Monikulttuurisuus on sekä rikkaus että haaste.

Työste-hankeverkoston muodostavat Metropolia Ammattikorkeakoulu, Herttoniemen seurakunta, Itä-Helsingin Lähimmäistyö Hely ry, Digital Living International Oy ja Myllypuro Seura ry. Hankkeessa ei ole haluttu rajata, kuka on työelämän ulkopuolella oleva. Työelämän ulkopuolella olevat voivat olla yhteiskunnan sisäpiirissä, sen reuna-alueella tai kokonaan sen ulkopuolella eläviä henkilöitä (vrt. Helne 2002). Näin ollen ei voida myöskään suoraan puhua syrjäytyneistä tai syrjäytymisvaarassa olevista. Toisaalta Helne (2002) toteaa, että ymmärrettiinpä syrjäytyminen sitten marginaalisuutena tai eksluusiona, syrjäytyminen on aina kuitenkin olemassa vain suhteessa muihin ihmisiin eikä ongelmia voida pitää yksilön tai ryhmän ominaisuutena.

Työste-hankkeessa ajatus on, että osallistujalle mahdollistetaan yhdessätoimijan asema riippumatta siitä, mikä hänen taustansa on. Mielekästä arjen toimintaa ei Myllypurossa kehitä mikään ulkopuolinen taho, vaan sitä kehittävät työelämän ulkopuolella olevat ihmiset yhdessä alueen ikäihmisten kanssa. Kehittäjäkumppaneina he siis määrittävät itse, millainen toiminta heille on merkityksellistä heidän omalla asuinalueellaan.
Käytännön toimintamalli ovat yhteiset työpajat, joissa ideoidaan ja suunnitellaan yhteistä toimintaa, joka integroidaan osaksi alueen muuta toimintaa. Ammattilaisten tehtävänä on luoda mielekkäänä pidetylle toiminnalle mahdollisuuksia.

Uudenlaisen toimintatavan kehittämiseen liittyvät kysymykset ovat:

1. Minkälainen toiminta edistää toimintakykyä? Kuka sen määrittää tai tietää? Mikä asema tai rooli toiminnan kehittäjälle eli työelämän ulkopuolella olevalle tulee antaa tai mahdollistaa?

2. Minkälaiseen kehittämistoimintaan osallistuminen vahvistaa työelämävalmiuksia ja työelämäedellytyksiä? Kehittämistoiminnan lähtökohtana on teoreettinen ymmärrys siitä, mitä työmarkkinoilla toimimisen taitoja jokaisella tulee olla, ja mitä valmiuksia vaaditaan työelämässä toimivalta ihmiseltä.

3. Miten yhdessä ideoitu, toimintakykyä edistävä toiminta siirtyy käytäntöön asuinalueella? Mitä verkostoja pitää rakentaa?

4. Mitkä ovat niitä oppimisen paikkoja tai tilanteita, joissa työelämävalmiudet vahvistuvat?

Edellä esitettyihin kysymyksiin vastauksia hakemalla Työste-hankkeessa rakennetaan uudenlaisen toimintatavan kuvaus eli siltausmalli.

\section{Kohteesta kehittäjäksi}

Työelämän ulkopuolella oleva henkilö kohtaa arjessaan monia eri tahoja, jotka pyrkivät tukemaan ja auttamaan häntä esimerkiksi asumiseen, toimeentuloon, etuisuuksiin, työllistymiseen tai kuntoutukseen liittyvissä kysymyksissä. Näissä yhteyksissä hän usein tulee kohdatuksi toiminnan kohteena, ja hänen osallistumisensa itseään koskevien asioiden käsittelyyn sekä päätöksentekoon jää vähäiseksi (vrt. Niiranen ym. 2011). Esimerkiksi kuntoutuksen asiakasyhteistyölain mukaan asiakkaan tarpeet tulee ottaa huomioon hänen asioidensa käsittelyssä, mutta silti asiakasta kuullaan harvoin yksilöllisesti ja hänen 


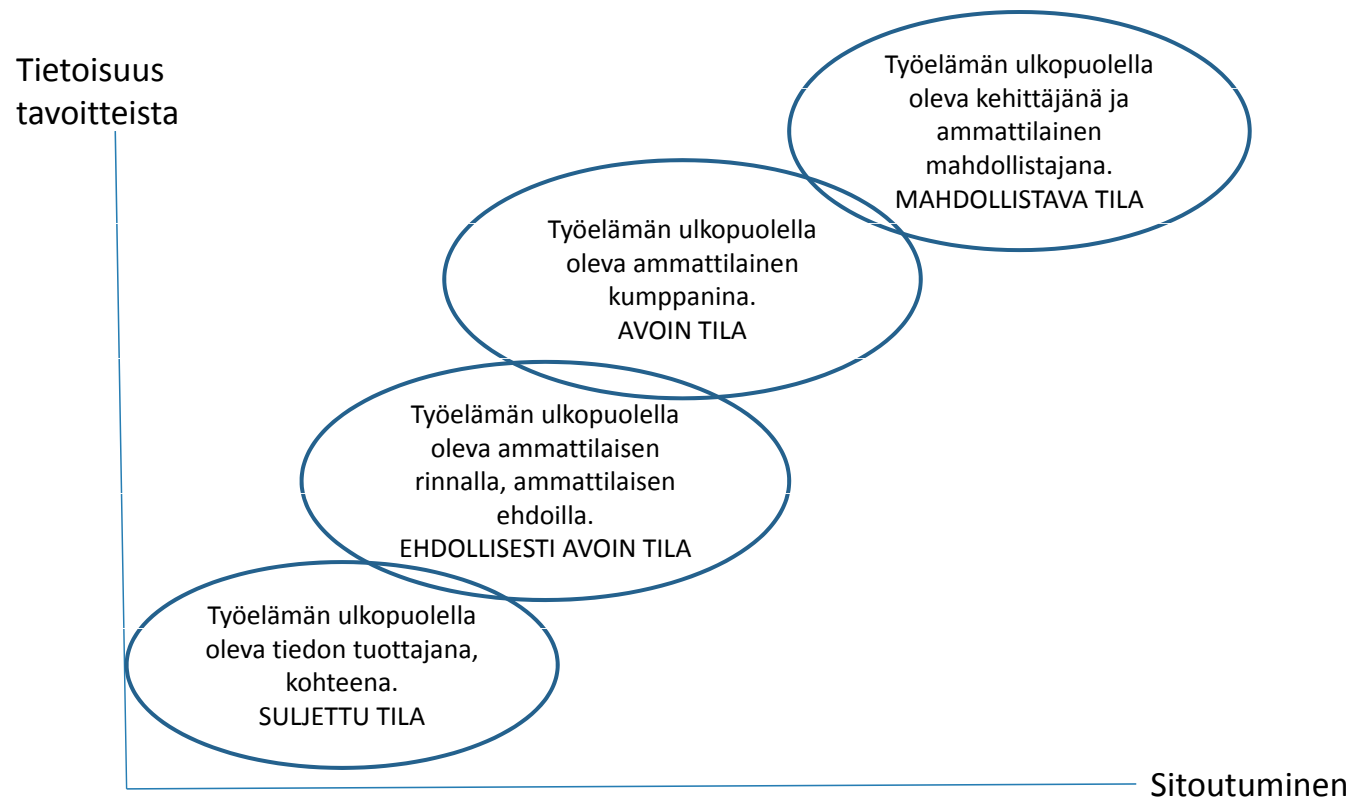

Kuva 1. Asiakasymmärryksen rakentuminen ja merkitys tavoitteiden ja sitoutumisen suhteen (mukaillen Nordlundia 2009).

näkökulmansa jää toisarvoiseksi (vrt. Saikku 2006). Tällaiset kohtaamiset ovat tehokkaita oppimistilanteita, joissa asiakas oppii helposti määrittämään itsensä työelämän ulkopuolella olevana kohteena.

Paradoksaalista on, että kun työelämän ulkopuolella oleva henkilö tulee häntä tukevissa toiminnoissa usein kohdatuksi kohteena, julkisessa puheessa edellytetään samalla, että hänen tulee olla aloitteellinen ja aktiivinen esimerkiksi oman työllistymisensä edistämisessä. Kyse ei ole siitä, etteivätkö kohtaamiset olisi asiakaslähtöisiä ja asianmukaisia. Kyse on siitä, mikä asema ja rooli asiakkaalle mahdollistetaan ja minkä oppimiskokemuksen hän saa asiakkaana (vrt. Mäkinen 2014). Kyse on asiakasymmärryksestä (kuva 1) ja siitä, miten työelämän ulkopuolella oleva oppii rakentamaan siltoja omien tarpeidensa ja toimintaympäristönsä tarjoamien mahdollisuuksien välille.

Niin sanotun suljetun tilan asiakasymmärryksen mukaisessa toiminnassa (Nordlund 2009) työelämän ulkopuolella oleva henkilö kohdataan asiakaskeskeisesti, mutta hänelle suodaan tiedontuottajan asema ammattilaisen määrittämissä asioissa. Hänestä tulee kohde. Käytännössä asiakaskeskeinen toiminta voi olla lomakkeiden täyttämistä tai haastatteluja, joissa ollaan aidosti kiinnostuneita asiakkaan asioista, mutta ammattilaisen ehdoilla. Ehdollisesti avoimessa tilassa työelämän ulkopuolella oleva ja ammattilainen toimivat rinnakkain, mutta edelleen ammattilaisen ehdoilla. Kohtaamisessa korostuu ammattilaisen asiantuntijuus, vaikka kyse on hyvinkin asiakaslähtöisestä toiminnasta. Avoimen tilan asiakasymmärrykseen perustuva toiminta rakentuu kumppanuuteen, jossa työelämän ulkopuolella oleva ja ammattilainen rakentavat yhdessä tavoitteet ja suunnittelevat toimenpiteitä. Molempien osapuolten sitoutuminen on vahvaa, ja työelämän ulkopuolella oleva on tietoinen päämäärästä. Kyse on siis paljon muustakin kuin esimerkiksi palveluprosessin organisoinnista. Kyse on asiakkaan kohtaamisesta, vuorovaikutuksen laadusta ja määrästä, molemminpuolisesta luottamuksesta sekä asiakkaan osallisuudesta (vrt. Mäkinen 2014). Mahdollistavan tilan asiakasymmärryksestä on kyse silloin, kun yksilö on itse omaa elämäänsä koskevien asioiden asiantuntija (vrt. Nordlund 2009). Ammattilaisen rooli on mahdollistaa tämä.

Jos ihminen tulee kohdatuksi suljetun tai 
ehdollisesti avoimen tilan asiakasymmärryksen mukaan, vahvistetaan hänen oppimiskokemustaan ulkoapäin ohjautuvasta toimijasta. Sen sijaan kokemus roolista, jossa ihminen toimii omaa elämäänsä ohjaavana ja määrittävänä kansalaisena, vahvistaa minäpystyvyyttä.

Työelämän ulkopuolella oleva ihminen ei lähtökohtaisesti ole potilas, kuntoutuja tai huollettava. Siksi on oleellista kohdata hänet kansalaisena, jonka elämään ei tietyllä hetkellä jostain syystä sisälly työsuhdetta ja sen tuomaa työtä toimintana. Työelämän ulkopuolella olevaa pitää tukea löytämään siltoja, joiden avulla hän saa kiinnittymiskohtia omaan toimintaympäristöönsä ja mahdollisuuksia löytää mielekästä tekemistä arkeensa, joka voi vahvistaa myös työelämään suuntautumista.

Muutos kohteesta kehittäjäksi ei onnistu helposti. Työelämän ulkopuolella olevalle tulee mahdollistaa aitoja, omaan elämään kiinnittyviä kohtia, joissa hän saa kokemuksen itselleen merkityksellisten asioiden kanssa työskentelystä. Mistä rakentuu merkityksellisyyden kokemus yhteisessä toiminnassa? Viimeaikainen työhyvinvointitutkimus tuo tähän mielenkiintoisen näkökulman. Muuttuvassa ja verkostoituvassa työelämässä työhyvinvoinnin kokemusta vahvistaa erityisesti se, että työntekijä tuntee tekevänsä työtä, joka tuo lisäarvoa asiakkaalle (vrt. Seppänen ym. 2014). Analogisesti työelämän ulkopuolella olevan kannalta hyvinvointia voi vahvistaa toiminta, jonka työelämän ulkopuolella oleva kokee tuovan lisäarvoa myös muille kuin hänelle itselleen. Lähin toimintaympäristö on tällöin oma asuinalue, ja työpaikan työntekijöitä ja asiakkaita vastaavia tahoja ovat tällöin alueen asukkaat.

\section{Yhteiskehittäminen siltana omaan arkeen}

Kehittäminen yhdessä tarkoittaa myös yhdessä toimimista. Yhdessä toimiminen voi toteutua eri tavoin (vrt. Harra 2014; Dennig \&t Yaholkovsky 2008). Se voi olla tiedon jakamista (information sharing), tai yhdessä tekeminen voi toteutua koordinointina (coordination) sopusointuisen toiminnan toteutta- miseksi. Se voi tarkoittaa myös yhteistyötä (cooperation), jossa toimitaan yhdessä sovittujen sääntöjen mukaisesti, tai se voi olla yhteistoimintaa (collaboration), jossa ryhmä ihmisiä luo yhdessä ratkaisuja tai strategioita synergisen vuorovaikutuksen kautta. Yhteistoimintaan liittyy muita vahvemmin ja monipuolisemmin konkreettinen toimintaorientaatio, asiantilojen muuttaminen ja pyrkimys yhdessä toimimiseen (Harra 2014). Yhdessä toimiminen ja asiakasymmärrys ovat toisiinsa liittyviä ilmiöitä.

Yhteiskehittämistä ohjaavat yhteistoiminnan lainalaisuudet. Yhteistoiminnassa keskeisiä asioita ovat Harran (2014) laatiman, tutkimuksiin perustuvan yhteenvedon mukaan halu ja tarve yhteistoimintaan, ammattilaisen luopuminen perinteisestä ammattilaiskäsityksestä, ammattilaisen kyky ja halu muotoilla yksilöllisiä palveluja, eri osallistujatahojen kyky osallistua aktiivisesti, jaettu valta, molemminpuolinen arvostus, molemminpuolinen riippuvuus, luottamus ja luotettavuus, avoin, rehellinen ja kunnioittava kommunikointi, jaetut tavoitteet ja aktiivisesti yhdessä rakennettu toiminnan päämäärä, prosessi ja tulokset, sopiva toimintaympäristö, sopivat vastuujärjestelyt, johtaminen ja hallinnointi sekä kumppanuuden tarkastus, arviointi ja seuranta. Osallistujien väliseltä suhteelta odotetaan kokemusten vaihtoa, asiantuntijuutta, vastavuoroisuutta ja joustavuutta.

Työste-hankkeessa yhteiskehitetään hyvää arkea omaan asuin- ja elinympäristöön. Kehittäjinä ovat työelämän ulkopuolella olevat henkilöt yhdessä ikäihmisten kanssa. Hyvää arkea ei määritetä ulkoapäin, vaan se luodaan yhdessä. Jotta yhteiskehittäminen onnistuu, tarvitaan osallistujille kohtaamispaikkoja, joissa syntyvät luottamus, yhdessä rakentuva päämäärä ja halu toimia. Yhteistoimintaan perustuva kehittäminen vaatii, ainakin alkuvaiheessa, aikaa. Yhteiskehittäminen on samalla myös osallistujien oppimisprosessi, joka tuo edetessään muutosta. Prosessissa on kyse yksilön ja ympäristön muutosprosessista. Tällöin lähestytään myös kuntoutuksen valtaistavan ja ekologisen paradigman mukaista ajattelua (Järvikoski 2013). 
Työste-hankkeessa yhteiskehittäminen luo myös mahdollisuuden sosiaalisen verkoston laajentamiseen paitsi työelämän ulkopuolella olevien kesken, myös heidän ja ikäihmisten välillä. Oppiminen, uusien mahdollisuuksien löytäminen omassa asuinympäristössä ja sosiaalinen osallisuus yhteiseen tekemiseen tukevat voimavarojen vahvistumista. Yhteiskehittäminen antaa myös mahdollisuuden vertaistuen hyödyntämiseen. Malli sopii saumatta nykyiseen kuntoutuskäsitykseen.

\section{Verkostokehittäminen sidoksena yhteiskuntaan}

Vaikka työttömyys ja työelämän ulkopuolella oleminen eivät sinällään ole terveysongelmia, monet tutkimustulokset osoittavat, että työttömät ovat keskimäärin sairaampia kuin muu väestö ja että työttömyyden pitkittyessä kokemus omasta terveydestä ja hyvinvoinnista heikkenee (Niiranen ym. 2011). Tämä tarkoittaa uudenlaisten toimintatapojen kehittämisen tarvetta. Monimuotoistuneet työelämän ulkopuolella olevien henkilöiden hyvinvointiongelmat vaativatkin aikaisempaan nähden moninaista verkostotyötä eri tahojen kesken (vrt. Karjalainen ym. 2008).

Työste-hankkeessa työtä vailla olevien ja ikäihmisten yhdessä ideoimiin, hyvää arkea rakentaviin aktiviteetteihin kiinnitetään alueen palveluntuottajista ja toimijoista niitä, joilla on intressi tuotetun idean suhteen. Kyse on kehittämisverkoston rakentamisesta (kuva 2). Hanketoiminnan alkuvaiheessa verkostokehittämisen ytimessä ovat hyvää arjen toimintaa ideoivat työtä vailla olevat henkilöt ja ikäihmiset ja näiden toimintaa mahdollistavat ja tukevat Työste-hankkeen projektityöntekijät. Verkostokehittämisen ytimessä tuotettujen, hyvää arkea tuovien aihioiden eteenpäin viemistä rakennetaan yhteisen intressin ympärille rakentuvan kehittämisverkoston toimintana.

Kehittämisverkosto muodostuu alueen palvelujen tuottajista ja muista toimijoista (kuviossa 2 ulkokehällä olevat tahot), joita yhdistää sama intressi. Oleellista on, että kehittämisverkosto toimii käytännössä niin, että siinä on aktiivisina toimijoina myös verkoston ytimessä olevia tahoja eli tässä yhteydessä työelämän ulkopuolella olevia ja ikäihmisiä. Työste-hankkeessa hankeverkoston projektityöntekijöiden tehtävä on tukea verkostojen rakentumista ja auttaa rakentamaan siltoja eri toimijoiden kesken.

Hankkeessa verkostokehittäminen on orgaanisesti rakentuvaa, sekä ihmisten välistä että organisaatioiden välistä verkostoitumista (vrt. Hibbert ym. 2008). Tällöin verkostorajat eivät ole ennakkoon määrättyjä eivätkä selviä. Lähtökohtana on ihmisten välinen orgaanisesti rakentuva sosiaalinen verkosto, joka määrittää kehittämisverkoston tarpeen. Analogisesti kyse on samasta ilmiöstä, jossa palvelut rakennetaan palvelun käyttäjän lähtökohdista ja jossa palvelun käyttäjä on myös palvelujensa kehittäjä. Palvelut taipuvat, eivät sen käyttäjät. Kyse on kansalaisten itsensä kehittämästä verkostotoiminnasta, jossa toimitaan yksityisen, julkisen ja kolmannen sektorin palvelujen rajapinnoilla asukkaiden lähtökohdista.

Verkosto on järkevä toimintatapa silloin, kun pitää reagoida muuttuviin tarpeisiin ja tarvitaan innovatiivisia ja joustavia ratkaisuja, joita ei ole selkeinä tarjolla (Järvensivu ym. 2010). Jos ratkaisu tuotetaan ulkopäin, pitää luottaa siihen, että ratkaisu saavuttaa toimijoiden luottamuksen. Verkostoituneen kehittämisen prosessi puolestaan alkaa siitä, että ensin pitää saada aikaan toimijoiden keskinäinen luottamus. Kun se syntyy, ratkaisujen kehittäminen ja niiden hyödyntäminen yhdessä mahdollistuvat. Kyse on oppimisprosessista, jossa ensin opitaan yhdessä ja sitten opitaan yhdessä oppimisesta. Samalla vahvistetaan ratkaisujen siirtymistä käytäntöön osana kehittämistä, ilman perinteistä - ja usein erittäin haasteellista - juurruttamisvaihetta.

Verkostoyhteistyön toimivuuden ydintekijät ovat tunteminen, luottamus ja sitoutuminen (Järvensivu ym. 2010). Yhteiskehittäminen tukee näitä tekijöitä, ja niitä tukee myös asiakasymmärryksen avoimessa tai mahdollistavassa tilassa tapahtuva kehittämisen tapa. Näin ollen Työste-hankkeessakin lähtökohtina olevat asiakasymmärrys, yhteiskehittäminen ja verkostotoiminta vahvistavat toinen toisiaan. 


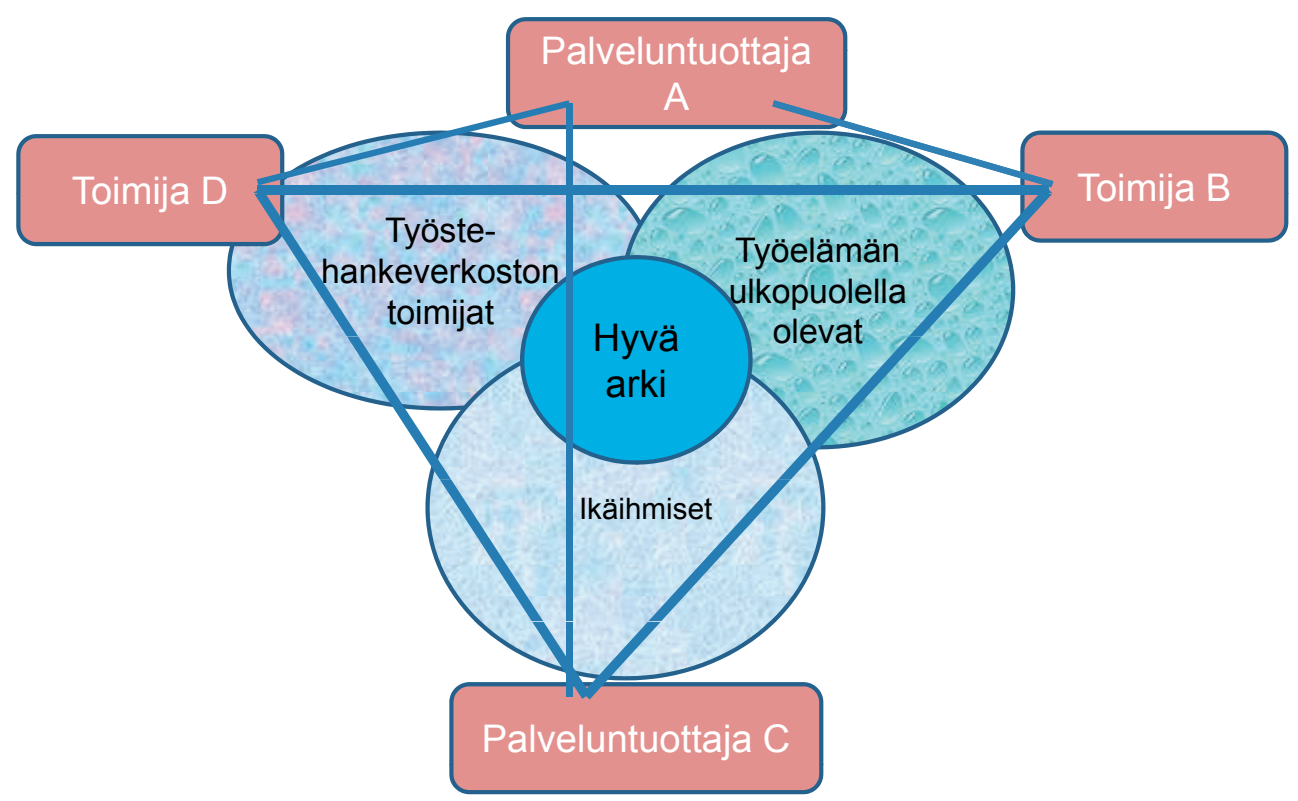

Kuva 2. Verkostossa toteutuva kehittäminen hankkeen alkuvaiheessa.

Kun työtä vailla olevan ihmisen määrittämien, hänen ja alueen asukkaiden hyvinvointia vahvistavien asioiden äärelle rakentuu kehittämisverkostoja, työtä vailla olevalle rakentuu samalla kiinnittymiskohtia yhteiskuntaan. Tällä on merkitystä syrjäytymisen vähentämisessä.

\section{Työelämävalmiuksia omaa asuinaluetta kehittämällä}

Työelämän ulkopuolella olevan ihmisen motivoituminen omien työelämävalmiuksien vahvistamiseen on haasteellista, jos näkymä työllistymisestä on kaukainen tai hän on jo luopunut mahdollisuudesta työllistyä. Kestävän työ- ja toimintakyvyn rakentumisen kannalta on tärkeää, että työelämän ulkopuolella olevilla henkilöillä on kiinnittymiskohtia ja mielekästä toimintaa omassa arjessaan, minkä kautta voi syntyä myös yhteys työelämään. Osallistuminen omassa lähiympäristössä mielekkäiden toimintojen kehittämiseen yhdessä alueen muiden toimijoiden kanssa vahvistaa osallisuuden tunnetta ja yhteisöllisyyttä.

Työelämän ulkopuolella olevien kohdalla on tarpeena vahvistaa yleisiä työelämäval- miuksia, jotka Ruohotien (2002) mukaan ovat elämän hallinta, kommunikaatiotaidot, ihmisten ja tehtävien johtaminen sekä innovaatioiden ja muutosten vauhdittaminen. Työelämävalmiudet kehittyvät aidoissa toimintaympäristöissä. Hankkeessa tapahtuvassa kehittämisessä ja kokeiluissa tulee olla samat elementit kuin hyvässä työssä: sen tulee olla tekijälleen merkityksellistä, antaa onnistumisen kokemuksia, mahdollistaa oppimista ja minäpystyvyyttä sekä kehittää itsensä johtamista. Toiminnalla tulee olla myös laajempaa merkitystä yhteisölle ja yhteiskunnalle.

Kun työelämän ulkopuolella oleville henkilöille mahdollistetaan aktiivinen toimijan rooli merkityksellisten asioiden kehittäjänä yhteiskunnassa, tämä vahvistaa työelämävalmiuksia, tukee toimintakykyä ja vähentää syrjäytymisriskiä (vrt. Arnkil \&t Spangar 2014). Ihmisten yhdessä toteuttama hyvän arjen kehittäminen heidän omalla asuinalueellaan luo oppimistilanteita, joissa eri-ikäiset ja eri elämäntilanteissa olevat kehittävät vuorovaikutustaitojaan, määrittävät yhteisiä päämääriä ja pohtivat keinoja päämäärien saavuttamiseksi uudella tavalla. 


\section{Lopuksi}

Työelämävalmiuksien rinnalla voidaan puhua myös työelämäkyvykkyydestä tai työmarkkinoilla toimimisen taidoista. Heikossa työmarkkina-asemassa oleville suunnatut välityömarkkinat ovat tarpeelliset ja vaativat edelleen kehittämistä. Näiden rinnalle tarvitaan myös uudenlaisia ratkaisuja ja uusia vaihtoehtoja. Yhdenvertaisuuden näkökulmasta on perusteltua kysyä, miten heikossa työmarkkina-asemassa olevien työmarkkinoilla toimimisen taitoja, työelämävalmiuksia, vahvistetaan. Heikommassa asemassa oleville pitää tarjota enemmän apua ja tukea, mutta tärkeää on saada aikaa toimintaa, jossa työelämässä tarvittava, kaikilta vaadittava osaaminen voi kehittyä.

\section{Elisa Mäkinen FT, yliopettaja, Metropolia Ammattikorkeakoulu}

Tuula Mikkola, VTT, yliopettaja, Metropolia Ammattikorkeakoulu

\section{Lähteet}

Arnkil R, Spangar T (2014) Promoting Enterprising Relations to Work - The discovery journey from My Generation to the present stage of My Generation at Work - and beyond. Luettavissa osoitteessa: http://urbact.eu/mygeneration-at-work. Luettu 2.3.2016.

Dennig PJ, Yaholkovsky P (2008) Getting to "We". Solidarity, Not Software, Generates Collaboration. Communications of the Acm, 51, 4, 19-24.

Harra T (2014) Terapeuttinen yhteistoiminta. Asiakkaan osallistumisen mahdollistaminen toimintaterapiassa. Acta Electronica Universitatis Lapponiensis 156

Heikkilä M (2000) Syrjäytymisen tutkimus 1990-luvulla. Teoksessa Heikkilä M, Karjalainen J (toim.) Köyhyys ja hyvinvointivaltion murros. Werner Söderström Lakitieto 0y, Tampere.

Helne T (2002) Syrjäytymisen yhteiskunta. Tutkimuksia 123, Stakes, Helsinki.

Hibbert P, Huxham C, Smith Ring P (2008) Managing Collaborative Inter-organizational Relations. In Cropper S, Huxham C, Ebers M, Smith Ring P (eds.) Handbook of Inter-Organizational Relations. Oxford: OUP.

Järvensivu T, Nykänen K, Rajala R (2010) Verkostojohtamisen opas. Verkostotyöskentely sosiaali- ja terveysalalla. Aalto-yliopisto, Helsinki.
Järvikoski A (2013) Monimuotoinen kuntoutus ja sen käsitteet. STM:n raportteja ja muistioita 43, Helsinki.

Karjalainen V, Saikku P, Pasuri A, Seppälä A (2008) Mitä on aktiivinen sosiaalipolitiikka kunnassa? Näköalapaikkana työvoiman palvelukeskukset. Raportteja 20, Stakes, Helsinki.

Mäkinen E (2014) Kuntoutujan uusi asema. Teoksessa Sipari S, Mäkinen E, Paalasmaa P (toim.) Kuntoutettavasta kehittäjäkumppaniksi. Metropolia Ammattikorkeakoulun julkaisusarja. Aatos-artikkelit 13, Helsinki.

Niiranen K, Hakulinen H, Huuskonen MS, Jahkola A, Räsänen K (2011) Työttömän työelämävalmiuksien tukeminen viranomaisverkostossa. Sosiaalilääketieteellinen aikakauslehti 48, 38-52.

Nordlund H (2009) Constructing customer understanding in front end of innovation. Acta Universitatis Tamperensis 1478.

OECD (2010) Sickness, Disability and Work. Breaking the Barriers. A Synthesis of Findings Across OESD Countries. Paris.

Ruohotie P (2002) Oppiminen ja ammatillinen kasvu. WSOY, Helsinki.

Saikku P (2006) Asiakasyhteistyötä uudella lailla? STM:n selvityksiä 47, Helsinki.

Seppänen L, Heikkilä H, Kira M, Lallimo J, Ruotsala R, Schaupp M, Toiviainen H, Uusitalo H, AlaLaurinaho A (2014) Palveluverkostojen muuttuvat toimintakonseptit. Asiakasymmärrys, välineet ja työhyvinvointi verkostoyhteistyössä. Työterveyslaitos, Helsinki.

von Hertzen-Oosi N, Vaittinen E, Ruoppila S, Virtanen P (2010) Kolmannen sektorin työ- ja elinkeinohallinnolle tuottamien palveluiden ja järjestettyjen työtilaisuuksien vaikutukset. Työ ja yrittäjyys 13, Työ- ja elinkeinoministeriön julkaisuja, Helsinki.

Vuorento M, Terävä K (2014) Osatyökyisen työssä jatkamisen ja työllistymisen tukeminen. Kirjallisuuskatsaus ja haastattelututkimus. Kuntoutussäätiön työselosteita 48, Helsinki. 